\title{
PEMBELAJARAN KEWIRAUSAHAAN DI SMA SELAMA PANDEMI COVID-19
}

\author{
Leny Noviani ${ }^{1}$, Adam Wahida ${ }^{2}$ \\ ${ }^{1}$ Universitas Sebelas Maret, lenynoviani@staff.uns.ac.id \\ ${ }^{2}$ Universitas Sebelas Maret, adamwahida@staff.uns.ac.id
}

\section{DOI}

https://doi.org/10.26740/jupe.v10n1.p1522

\author{
Article history \\ Received \\ 29 October 2021 \\ Revised \\ 7 November 2021 \\ Accepted \\ 15 November 2021
}

\section{How to cite}

Noviani, L \& Wahida, A. (2022). Pembelajaran Kewirausahaan di SMA Selama Pandemi Covid-19. Jurnal Pendidikan Ekonomi (JUPE), 10(1), 1522. https://doi.org/10.26740/jupe.v10n1.p1522

Kata Kunci: pembelajaran kewirausahaan, pandemi

Keywords: entrepreneurship learning, pandemic

\section{Corresponding author}

Leny Noviani

lenynoviani@staff.uns.ac.id

\begin{abstract}
Abstrak
Tujuan penelitian ini adalah: 1) untuk mendeskripsikan pelaksanaan pembelajaran kewirausahaan di SMA selama pandemi Covid-19, dan 2) memberikan solusi bagaimana meningkatkan kualitas pembelajaran kewirausahaan. Penelitian ini menggunakan metode deskriptif. Pengumpulan data menggunakan kuesioner. Responden sejumlah 1.347 siswa SMA kelas XI dan XII dari 20 SMA di Sragen. Hasil penelitian menunjukkan bahwa selama pandemi Covid-19 pembelajaran kewirausahaan lebih banyak mengajarkan tentang teori $(69,1 \%)$. Metode yang digunakan guru saat mengajar pada umumnya adalah penugasan $(54,8 \%)$ tentang tugas/pekerjaan rumah tentang teori kewirausahaan. Platform digital yang digunakan guru adalah google class room $(39,3 \%)$, zoom $(9,6 \%$, WhatsApp (25,5\%), google meet (16\%), dan platform lainnya 9,5\%. Secara umum, siswa menilai bahwa pelajaran kewirausahan sesuai dengan kebutuhan dan memberikan bekal untuk menjadi wirausaha. Sebanyak 64,5\% siswa merasa antusias mengikuti pelajaran. Perbaikan pembelajaran kewirausahaan menurut persepsi siswa adalah: materi lebih aplikatif dan menarik, dilatihkan cara mengatasi masalah riil, dan diimbangi dengan praktik. Pendidikan kewirausahaan dapat dilakukan melalui kegiatan intrakurikuler, kokurikuler, dan ekstrakurikuler.

\section{Abstract}

The objectives of this study are: 1) to describe the implementation of entrepreneurship learning in high school during the Covid-19 pandemic, and 2) to provide solutions on how to improve the quality of entrepreneurship learning. This study uses a descriptive method. Collecting data using a questionnaire. Respondents were 1,347 high school students in grade XI and XII from 10 high schools in Sragen The results showed that during the Covid-19 pandemic, entrepreneurship learning taught more about theory $(69.1 \%)$. The method used by teachers when teaching is assignments (54.8\%) on assignments/homework on entrepreneurship theory. The digital platforms used by teachers are google class room $(39.3 \%)$, zoom $(9.6 \%$, WhatsApp (25.5\%), google meet (16\%), and other platforms $9.5 \%$. In general, students assessed that entrepreneurship lessons are in accordance with their needs and provide provisions to become entrepreneurs. As many as $64.5 \%$ of students feel enthusiastic about participating in lessons. Improvements in entrepreneurship learning according to students' perceptions are: the material is more applicable and interesting, trained in how to overcome real problems, and balanced with practice. Entrepreneurship education can be done through intracurricular activities in class, co-curricular, and extra-curricular.
\end{abstract}




\section{PENDAHULUAN}

SMA dirancang untuk mempersiapkan peserta didik melanjutkan ke Pendidikan tinggi, namun pada kenyataannya tidak semua lulusan SMA melanjutkan Pendidikan. Tingkat pengangguran terbuka berdasarkan tingkat pendidikan per Agustus 2019 menunjukan bahwa pengangguran lulusan SMA sebesar 1,9 juta, lulusan SMK 1,7 juta, lulusan SMP sebesar 1,1 juta dan lulusan SD ke bawah sebesar 382 ribu (Badan Pusat Statistik, 2019). Pada tahun 2019, Di Kabupaten Sragen jumlah pengangguran lulusan SMA sebanyak 5.543 dari jumlah total pengangguran 15.716 jiwa (Sragen, 2020).

Tingginya tingkat pengangguran khususnya lulusan SMA akan menyebabkan multiflier effect yaitu rendahnya tingkat pendapatan perkapita, tingginya beban tanggungan keluarga, dan kemudian menurunkan tingkat kesejahteraan masyarakat. Kondisi demikian diperparah dengan adanya pandemi Covid-19 yang membawa dampak pada krisis ekonomi. Upaya yang dapat dilakukan untuk mengatasi hal ini adalah dengan meningkatkan jumlah wirausaha. Salah satu upaya menumbuhkan minat berwirausaha adalah program pendidikan kewirausahaan untuk mengajarkan dan mendorong perilaku wirausaha ((Mcstay, 2008); (Kasmir, 2006); (Mulyani, 2014))

Pendidikan kewirausahaan merupakan bagian integral dari struktur kurikulum pada jenjang SMA yang berfokus pada pengembangan pola pikir atau semangat kewirausahaan siswa karena mungkin hal ini akan menjadi pusat dari tindakan kewirausahaan lainnya. Sekolah perlu memberikan wawasan kepada peserta didik tentang jenis kewirausahaan yang disesuaikan dengan ciri khas dan potensi daerah, termasuk keunggulan daerah.

Program kewirausahaan melalui mapel prakarya dan kewirausahaan diharapkan mendorong peserta didik menjadi kreatif, mandiri, serta berani membuka usaha sendiri. Pendidikan kewirausahaan merupakan usaha terencana untuk meningkatkan pengetahuan, minat dan kompetensi siswa agar mampu mengembangkan potensi dirinya melalui perilaku kreatif dan inovatif (Purwana, D. \& Wibowo, 2017) dengan tujuan menumbuhkan dan mengembangkan potensi berwirausaha. Mengingat masih tingginya tingkat pengangguran terbuka dari kalangan terdidik, termasuk lulusan SMA maka pemberian pendidikan kewirausahaan dianggap sangat penting untuk menanamkan jiwa wirausaha kepada siswa. Hal ini sejalan dengan penelitian di salah satu universitas di Nigeria (Philip et al., 2016) yang menunjukkan bahwa menurut persepsi mahasiswa, pendidikan kewirausahaan dirasakan secara positif di semua dimensi dan menunjukkan hubungan positif yang kuat antara persepsi dan niat kewirausahaan. Membangun persepsi positif tentang pendidikan kewirausahaan di kalangan siswa adalah dasar untuk mencapai tujuan utamanya. Pendidikan kewirausahaan dianggap sangat penting untuk memberikan kesempatan bagi siswa menjadi pribadi yang inovatif, kreatif, mandiri, dan menjadi pemimpin yang mampu menghadapi tantangan. Oleh karena itu, pendidikan kewirausahan merupakan upaya untuk mempersiapkan lulusan menjadi wirausaha sehingga mampu berkontribusi pada pembangunan ekonomi.

Berbagai macam metode telah diidentifikasi untuk mendukung pendidikan kewirausahaan. Pendekatan yang paling sering dilakukan dalam pendidikan kewirausahaan adalah pendekatan berbasis masalah dan memberikan pengalaman untuk mengembangkan kewirausahaan (Bliemel, 2013). Pendidikan kewirausahaan dengan pendekatan pengalaman secara bertahap mendorong siswa keluar dari zona nyaman mereka dan memasuki dunia kewirausahaan yang menarik. Desain kurikulum memperkenalkan tiga tingkat kesempatan belajar berdasarkan pengalaman: pengalaman tidak langsung melalui pembicara tamu dan mentor, pengalaman virtual melalui penawaran di kelas, serta investor nyata, dan jika memungkinkan pengalaman langsung melalui pitching ideide mereka di acara jaringan industri dan kompetisi pitch. Pendekatan bertahap ini memudahkan siswa dalam proses bertindak dan berpikir seperti wirausahawan sejati.

Oleh karena itu, pelaksanaan pembelajaran kewirausahaan perlu menerapkan strategi pembelajaran yang dapat menumbuhkan jiwa wirausaha siswa. Kebijakan pemerintah yang dituangkan dalam SE Mendikbud No. 4 Tahun 2020 bahwa Belajar dari Rumah melalui pembelajaran daring untuk memberikan pengalaman belajar yang bermakna dan difokuskan pada pendidikan kecakapan hidup. Kecakapan hidup diperlukan oleh seseorang dalam kehidupannya ((Brolin, 1989); (PH, 2002). Berdasarkan Keputusan Mendikbud No. 719/P/2020 tentang Pedoman Pelaksanaan Kurikulum pada Satuan Pendidikan dalam Kondisi Khusus Pada saat pandemi, sekolah diberikan flesibilitas dalam penyederhanaan kurikulum, sehingga siswa tidak lagi dibebani tuntutan menuntaskan seluruh capaian kurikulum dan dapat berfokus pada pendidikan dan pembelajaran yang esensial dan kontekstual. Pada kenyataannya, pembelajaran di sekolah masih cenderung teoritik dan tidak terkait dengan lingkungan siswa (Blazely, 1997). Begitu pula saat pembelajaran daring, belum optimalnya penggunaan pendekatan kontekstual, guru masih fokus pada pencapaian tuntutan kompetensi pada kurikulum yang sifatnya teoritis belum optimalnya penggunaan pendekatan kontekstual dengan penyampaian materi melalui platform WhatApss, Google Classroom, dan Google meet, (Noviani et al., 2020).

Pembelajaran kewirausahaan, baik yang dilaksanakan secara luring maupun daring sebaiknya menggunakan pendekatan berbasis masalah dan pengalaman siswa. 
Namun pada kenyataannya, pembelajaran daring mempunyai beberapa kendala. (Mustakim, 2020) dalam penelitiannya menjelaskan bahwa kendala yang dihadapi dalam pembelajaran daring ini terdapat pada jaringan internet yang tidak stabil, pulsa kuota internet terbatas, tugas terlalu banyak, sulit fokus, pulsa kuota terbatas, aplikasi yang rumit, dan lebih senang dengan pembelajaran tatap muka. Berbeda dengan hasil penelitian Nguyen (Nguyen, 2015) yang menyimpulkan bahwa hasil belajar pembelajaran online sebanding dengan pembelajaran tatap muka, lebih dari 350 studi tentang jarak dan pendidikan online sejak tahun 1928, 70\% tidak ada perbedaan yang signifikan dalam hasil pembelajaran namun terdapat heterogenitas yang signifikan pada hasil belajar peserta didik untuk berbagai aktivitas. Pembelajaran daring juga memberikan sebuah pengalaman baru bagi peserta didik dalam hal belajar. Salah satu keberhasilan yang diraih adalah pembelajaran daring menjadikan sebuah pembelajaran tanpa batasan ruang dan waktu dengan penyampaian pembelajaran dari berbagai sumber internet, bahan pembelajaran relatif mudah diakses diperbarui, dan semakin canggihnya teknologi informasi serta telekomunikasi memudahkan peserta didik belajar dan berdiskusi dengan para ahli di bidang yang diminati (Raharjo, 2016)

Tantangan bagi guru, khususnya guru mata pelajaran prakarya dan kewirausahaan adalah bagaimana melaksanakan pembelajaran daring yang berkualitas untuk membekali siswa pengetahuan tentang kewirausahaan dan nilai-nilai kewirausahaan sehingga dapat menumbuhkan jiwa kewirausahaan siswa. Berdasarkan uraian tersebut di atas, tujuan penelitian ini adalah untuk: 1) mendeskripsikan pelaksanaan pembelajaran kewirausahaan di SMA selama pandemi Covid-19, dan 2) memberikan solusi bagaimana meningkatkan kualitas pembelajaran kewirausahaan.

\section{METODE}

Penelitian ini merupakan penelitian deskriptif. Pengumpulan data dilakukan melalui survey kepada 1.347 siswa SMA kelas XI dan XII SMA yang berasal dari 20 sekolah yang berada di Kabupaten Sragen Jawa Tengah. Survey dilakukan untuk menjaring informasi mengenai pelaksanaan pembelajaran kewirausahaan selama pandemi Covid-19. Pengambilan sampel dilakukan dengan teknik convinience sampling. Pengambilan sampel ini dilakukan dengan memilih sampel secara bebas siapa bersedia mengisi angket. Pemilihan metode convinience sampling diambil berdasarkan ketersediaan dan kemudahan mendapatkannya. Dalam penelitian ini, sampel di ambil secara acak dari semua siswa SMA di Kabupaten Sragen Pengambilan sampel yang dilakukan dengan cara menyebarkan link google form kepada siswa SMA di Kabupaten Sragen. Dalam batas waktu yang telah ditetapkan peneliti, siswa yang bersedia mengisi angket sebanyak 1.347. Data yang terkumpul, dianalisis dengan analisis deskriptif. Selain itu, juga menggunakan studi literatur untuk menemukan alternatif solusi peningkatan kualitas pembelajaran kewirausahaan. Pertanyaan pada angket terbagi menjadi dua jenis yaitu pertanyaan terbuka dan pertanyaan tertutup. Pertanyaan terbuka untuk menjawab jenis kegiatan praktik kewirausahaan yang telah dilaksanakan oleh guru. Pertanyaan tertutup meliputi: jenis kelamin, tingkat/kelas, cita-cita siswa, dan persepsi pelaksanaan pembelajaran kewirausahaan yang telah diikutinya. Pertanyaan yang terkait persepsi pelaksanaan pembelajaran meliputi penggunaan media, metode pembelajaran, pengelolaan kelas, dan penilaian yang dilakukan oleh guru. Pengukuran menggunakan skala likert untuk mengukur persepsi siswa terhadap pelaksanaan pembelajaran kewirausahaan yang meliputi: Data dianalisis dengan menghitung persentase hasil skor yang telah diperoleh.

\section{HASIL DAN PEMBAHASAN}

Berdasarkan data yang terkumpul, berikut profil responden.

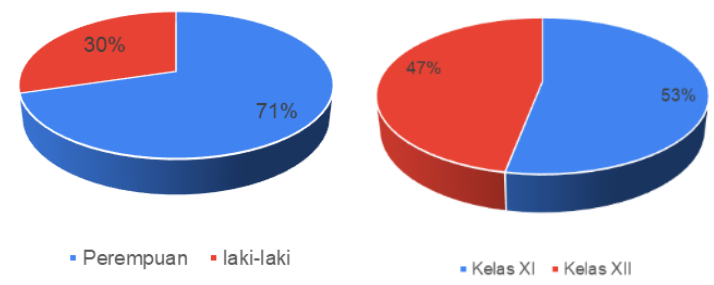

Gambar 1. Profil Responden

Siswa yang bercita-cita menjadi wirausaha hanya sebanyak 215 orang (16\%) dari 1.347 responden. Sebagian besar siswa menginginkan menjadi pegawai negeri sipil $(63 \%)$, karyawan swasta $(15,8 \%)$ dan lainnya $(5,2 \%)$. Minat siswa untuk menjadi wirausaha masih tergolong rendah. Banyak faktor yang mempengaruhi minat siswa untuk menjadi wirausaha. Minat terhadap kewirausahaan dapat dipengaruhi oleh keyakinan, proses berpikir, perilaku, pengalaman dan lingkungan sosial (Iwu et al, 2019). Minat merupakan faktor penting untuk menumbuhkan perilaku wirausaha karena melalui minat seseorang secara sadar akan berencana untuk melakukan perilaku mendirikan sebuah bisnis. Penelitian Asep Munawar dan Suryana (Munawar \& Suryana, 2020) menunjukkan bahwa pengetahuan kewirausahaan berpengaruh terhadap intensi berwirausaha siswa. Pengetahuan kewirausahaan siswa SMA di Kabupaten Sragen diperoleh melalui pembelajaran kewirausahaan. Oleh karena itu perlu diketahui tentang pelaksanaan 
pembelajaran kewirausahaan selama pandemi Covid-19 pada jenjang SMA di Kabupaten Sragen.

Berdasarkan persepsi siswa terhadap pelaksanaan pembelajaran kewirausahaan selama Pandemi Covid-19 adalaha sebagai berikut: platform digital yang digunakan oleh guru kewirausahaan selama pembelajaran daring adalah sebagai berikut: adalah google class room $(39,3 \%)$, zoom $(9,6 \%$, WhatsApp $(25,5 \%)$, google meet $(16 \%)$, dan platform dilainnya $9,5 \%$. Metode pembelajaran yang sering digunakan selama pembelajaran daring adalah $54,8 \%$ siswa menyatakan bahwa guru lebih sering memberi tugas atau pekerjaan rumah terkait dengan pemahaman teori kewirausahaan baik melalui google class room maupun WhatsApp. 10,8\% siswa menyatakan bahwa guru menyampaikan materi dengan metode ceramah, 15,9\% dengan menggunakan metode diskusi, dan 18,5\% siswa menyatakan bahwa guru juga menggunakan metode praktik membuat produk. Praktik kewirausahaan yang sering dilakukan guru adalah membuat kerajinan dari barang bekas. Praktik kewirausahaan lainnya adalah melakukan pengolahan makanan dan membuat sabun cuci tangan. Praktik yang juga dilakukan adalah praktik menjual makanan.

Pelaksanaan pembelajaran kewirausahaan selama pandemi Covid-19 menurut 69,1\% siswa, bahwa guru lebih sering menyampaikan tentang teori kewirausahaan. Sebanyak 23,5\% siswa diajarkan praktik tentang pembuatan produk kerajinan, $6 \%$ siswa menyatakan pernah dilatihkan atau praktik pengolahan bahan makanan tradisional dan bahan makanan dari bahan nabati, dan sisanya $1,4 \%$ siswa menyatakan dilatihkan atau praktik pada aspek rekayasa. Kegiatan praktik dilakukan secara mandiri di rumah. Produk hasil karya siswa di foto dan dikirimkan melalaui WhatApps atau Google Class Room.

Pembelajaran kewirausahaan pada saat pandemi Covid pada jenjang SMA di Kabupaten Sragen lebih banyak menyampaikan secara teoritis, sedangkan kegiatan praktikum tidak dilakukan. 69,49\% atau 936 siswa menyatakan bahwa tidak pernah ada kegiatan praktik kewirausahaan selama Pandemi. Sedangkan 30,51\% siswa menyatakan bahwa selama Pandemi Covid, kegiatan praktik kewirausahaan tetap dilakukan. Praktik kewirausahaan yang dilaksanakan di SMA sebagai berikut: membuat makanan olahan nusantara baik olahan kering maupun basah, membuat kerajinan dari barang bekas, membuat anyaman, membuat sabun cuci piring, praktik menjual, membuat masker, membuat pot bunga, dan membuat tempat tisu. Sebagian besar praktik kewirausahaan yang dilakukan adalah praktik membuat kerajinan baik dari barang bekas maupun dari bahan baku lainnya. Penilaian yang dilakukan oleh guru, fokus pada pencapaian aspek kognitif. Penilaian yang dilakukan guru berupa penyelesaian soal-soal yang terdapat di buku pegangan siswa, soal essai yang dibagikan oleh guru melalui platform yang telah ditentukan

Pembelajaran kewirausahaan di sekolah khususnya di jenjang SMA bertujuan untuk mengenalkan konsep awal kewirausahaan, menumbuhkan minat dan mengembangkan potensi wirausaha (Kemendikbud, 2019). Oleh karena itu pembelajaran kewirausahaan di SMA dilaksanakan secara eksploratif dan melalui pembelajaran yang bersifat simulasi dengan berbagai model pembelajaran yang mengarah pada keterampilan berpikir dan kreativitas. Penanaman jiwa kewirausahaan tidak hanya dibebankan kepada mata pelajaran prakarya dan kewirausahaan, namun dapat juga menjadi kokurikuler untuk mata pelajaran yang lain. Bahkan kewirausahaan dapat pula dilaksanakan melalui kegiatan ekstrakurikuler.

Berdasarkan uraian di atas, berikut disajikan berbagai solusi tentang upaya meningkatkan kualitas pembelajaran kewirausahaan di sekolah.

\section{Proyek Kewirausahaan melalui kegiatan intrakurikuler}

Pendidikan kewirausahaan melalui kegiatan intrakurikuler di jenjang SMA dibebankan melalui mata pelajaran Prakarya dan Kewirausahaan. Pembelajaran kewirausahaan sebaiknya tidak hanya melalui pendekatan teoritis saja, namun perlu melatihkan nilai-nilai kewirausahaan selama pembelajaran. Berdasarkan survei, menunjukkan bahwa sebagian besar guru kewirausahaan menyampaikan teori kewirausahaan melalui ceramah, mengirimkan materi kepada siswa, dan meminta siswa menonton video tentang materi kewirausahaan.

Dalam pembelajaran kewirausahaan, sebaiknya pendekatan yang dipilih guru juga dapat merangsang siswa untuk berpikir kreatif. Banyak tema atau potensi yang menjadi keunggulan di setiap daerah yang dapat dikembangkan oleh siswa secara berkelompok. Pengembangan potensi lokal ini dilatihkan guru melalui kegiatan proyek. Dengan pembelajaran proyek maka nilainilai kewirausahaan secara tidak langsung diajarkan dan dilatihkan, sedangkan konten materi kewirausahaan tidak hanya sebatas teoritis saja namun siswa dapat menggunakan pengetahuan yang dimiliki dalam merencanakan dan mengembangkan potensi lokal yang ada di daerahnya.

Pendekatan pembelajaran yang dapat dipilih untuk menumbuhkan dan melatihkan nilai-nilai kewirausahaan siswa adalah pembelajaran berbasis proyek (Project Based Learning/PjBL). Kajian empiris menunjukkan bahwa pelaksanaan pembelajaran berbasis proyek di Jurusan Manajemen Universitas Ciputra menghasilkan 91\% usaha yang dilaksanakan oleh kelompok usaha dan sekitar 33\% target tercapai (Tanjaya \& Radianto, 2020). Penelitian Widiharto dkk (Widiarto, Chr. Argo, Wiwik Kusdaryani, 2015) menggambarkan bahwa pembelajaran berbasis 
proyek efektif meningkatkan kewirausahaan siswa. Pembelajaran berbasis proyek sangat baik jika dipadukan dengan kegiatan Kewirausahaan. Implementasi pembelajaran proyek dapat meningkatkan motivasi serta gambaran diri yang positif pada diri siswa (Doppelt, 2003). Demikian pula penelitian Endang Mulyani (Mulyani, 2014) menunjukkan bahwa model pembelajaran proyek yang diterapkan dalam kelas eksperimen lebih efektif untuk meningkatkan sikap kewirausahan, minat berwirausaha, dan prestasi belajar, namun dalam hal meningkatkan perilaku kewirusahaan model yang diterapkan di kelompok kontrol dan eksperimen tidak berbeda efektivitasnya. Sejalan dengan penelitian sebelumnya, Wiwi Wikanta dan Yuni Gayatri (Wikanta \& Gayatri, 2017) menyatakan bahwa penerapan model pembelajaran berbasis proyek cukup efektif dalam menanamkan karakter kewirausahaan. Pendekatan yang sering dilakukan untuk mengembangkan kewirausahaan adalah belajar sambil melakukan, pekerjaan proyek, proyek dengan klien yang sebenarnya, kerja tim, lokakarya, studio, pendekatan berbasis masalah (Matlay \& Carey, 2007). Selain proyek, model pembelajaran design thinking dapat dipilih dalam pengembangan kewirausahan di sekolah (Kemendikbud, 2019).

Pembelajaran dengan PjBLmelibatkan siswa dalam pembelajaran yang mengkaitkan isu dunia nyata, menemukan masalah dengan penuh arti, kemudian beraksi dalam kolaborasi untuk menciptakan solusi permasalaha melalui kegiatan merancang, membuat, dan menampilkan produk yang dapat bermanfaat bagi masyarakat (Bender, 2012). Pembelajaran proyek pada mata pelajaran Prakarya dan Kewirausahaan terdiri dari 4 aspek yang dapat pelajari yaitu kerajinan, budidaya, rekayasa dan pengolahan. Tujuan dari mata pelajaran ini adalah melatihkan siswa untuk berekspresi secara kreatif, melatihkan keterampilan menciptakan karya baik karya jadi maupun dalam bentuk ide/gagasan, dan menumbuhkan jiwa wirausaha melalui penciptaan karya, megemas, dan usaha menjual produk.

Dalam pelaksanaan $\mathrm{PjBL}$, guru dapat mengarahkan siswa untuk memanfaatkan sumber daya yang ada di lingkungan sekitar sekaligus dilatihkan untuk dapat mengembangkan potensi lokal. Oleh karena itu, guru dan siswa perlu mengidentifikasi keungulan potensi lokal yang ada di daerahnya, sebagai contoh di Kabupaten Sragen terdapat obek wisata Gunung Kemukus. Potensi tersebut dapat digunakan sebagai tema utama dalam melatihkan 4 aspek pada mata pelajaran prakarya dan kewirausahaan. Sebagai contoh pada aspek kerajinan, tema Gunung Kemukus menjadi inspirasi mengembangkan motif batik samudro, motif rantai, dan motif lain yang identik dengan tema obyek wisata tersebut. Siswa juga dapat berkreasi membuat aneka kerajinan dengan mengusung tema Gunung Kemukus. Pada aspek pengolahan, siswa berkreasi mengembangkan aneka olahan yang menjadi ciri khas daerah setempat misalkan Jenang "Jadi" (dodol), aneka keripik, dan makanan khas Sragen. Pengemasan produk jadi dapat dikembangkan dengan menampilkan icon yang mewakili obyek wisata tersebut baik dalam bentuk tulisan maupun simbol.

Pendekatan lain untuk menumbuhkan jiwa kewirausahaan siswa adalah dengan model design thinking yang menyajikan pendekatan solusi untuk memecahkan masalah. Pendekatan ini lebih efektif jika dilakukan dalam kelompok siswa. Langkah model design thingking ini adalah proses mengenali keinginan atau selera konsumen, merumuskan masalah dan solusi pemecahan masalah, proses pengumpulan ide melalui curah pendapat agar diperoleh berbagai pandangan atau alternatif dari masingmasing anggota kelompok. Selanjutnya, kelompok siswa membuat purwarupa dan mengujinya. Salah satu bentuk pengujian adalah dengan meminta calon konsumen untuk menilai dan memberikan saran perbaikan atas purwarupa yang telah dibuat siswa. Hasil pengujian dijadikan dasar untuk perbaikan.

\section{Proyek Kewirausahaan melalui kegiatan kokurikuler}

Kokurikuler adalah kegiatan untuk memperdalam dan memperkaya materi pelajaran yang telah dilaksanakan dalam kegiatan intrakurikuler. Kegiatan kokurikuler dapat dilaksanakan melalui kegiatan kelompok maupun secara individu. Kegiatan kokurikuler dapat dilaksanakan secara terintegrasi dengan mata pelajaran lainnya. Pendidikan kewirausahaan berbasis intrakurikuler tidak mampu memberikan penekanan yang signifikan terhadap keminatan berwirausaha mahasiswa, sebaliknya dengan pendidikan pendekatan kokurikuler mampu memberikan peningkatan yang signifikan terhadap keminatan kewirausahaan dan memberikan pengaruh positif bagi mahasiswa (Purusottama \& Akbar, 2019). Di Amerika Serikat, perguruan tingg telah mengembangkan kegiatan kurikuler dan kokurikuler dalam melibatkan semua mahasiswa dalam inovasi dan kewirausahaan (McClure, 2015). Kokurikuler mendukung program kurikuler yang ditetapkan oleh institusi pendidikan baik sekolah maupun perguruan tinggi.

Pembelajaran kewirausahaan melalui kegiatan kokurikuler dapat dilakukan dengan cara memetakan kompetensi dasar atau capaian pembelajaran pada berbagai mata pelajaran yang ada di kurikulum sekolah. Hasil pemetaan kompetensi dasar atau capaian pembelajaran dapat diajarkan atau diperdalam melalui tugas-tugas proyek seperti podcast, mengembangkan aplikasi, membuat karya siswa dalam bentuk produk maupun jasa lainnya. Kegiatan kewirausahaan melalui kolaborasi dengan mata pelajaran lain akan membentuk proses berpikir kritis dan berpikir kreatif melihat segala sesuatu dari berbagai perspektif keilmuan. Pilihan bentuk kegiatan kokurikuler dapat bervariasi sesuai keinginan siswa. 
Kolaborasi keterlibatan guru mata pelajaran Prakarya dan Kewirusahaan, Ekonomi, dan Bahasa Indonesia dapat berkolaborasi dalam membimbing kokurikuler siswa mulai dari identifikasi masalah, menemukan solusi, menciptakan produk baik berwujud maupun ide/gagasan, memproduksi produk, memasarkan produk baik offline maupun secara online, dan menyusun laporan.

Contoh implementasi kegiatan pendidikan kewirausaah melalui kokurikuler sebagai berikut: pertama, melakukan pemetaan kompetensi dasar mata pelajaran kelas X pada mata pelajaran Prakarya dan Kewirusahaan, Ekonomi, dan Bahasa Indonesia.

Tabel 1. Pemetaan Kompetensi Dasar Mata Pelajaran dalam Kegiatan Kokurikuler

\begin{tabular}{|c|c|c|}
\hline \multirow{2}{*}{$\begin{array}{c}\text { Mata } \\
\text { Pelajaran }\end{array}$} & \multicolumn{2}{|c|}{ Kompetensi Dasar } \\
\hline & Pengetahuan & Keterampilan \\
\hline PPKn & $\begin{array}{l}3.4 \text { merumuskan } \\
\text { hubungan } \\
\text { pemerintah pusat dan } \\
\text { daerah menurut } \\
\text { UUD } 1945\end{array}$ & $\begin{array}{l}\text { 4.4 Merancang dan } \\
\text { melakukan penelitian } \\
\text { sederhana ttg } \\
\text { hubungan pemerintah } \\
\text { pusat dan daerah } \\
\text { setempat menurut } \\
\text { UUD1945 }\end{array}$ \\
\hline $\begin{array}{c}\text { Bahasa } \\
\text { Indonesia }\end{array}$ & $\begin{array}{l}3.2 \text { menganalisis isi } \\
\text { dan aspek } \\
\text { kebahasaan dari } \\
\text { minimal dua teks } \\
\text { laporan hasil } \\
\text { observasi }\end{array}$ & $\begin{array}{l}4.2 \\
\text { mengkonstruksikan } \\
\text { teks laporan dengan } \\
\text { memperhatikan isi } \\
\text { dan aspek kebahasaan } \\
\text { baik lisan maupun } \\
\text { tulis }\end{array}$ \\
\hline Ekonomi & $\begin{array}{l}3.3 \text { Menganalisis } \\
\text { peran pelaku } \\
\text { ekonomi dalam } \\
\text { kegiatan ekonomi }\end{array}$ & $\begin{array}{l}\text { 4.3 Menyajikan hasil } \\
\text { analisis peran } \\
\text { pelaku ekonomi } \\
\text { dalam kegiatan } \\
\text { ekonomi }\end{array}$ \\
\hline $\begin{array}{l}\text { Prakarya } \\
\& \\
\text { Kewira- } \\
\text { usahaan }\end{array}$ & $\begin{array}{l}3.3 \text { menganalisis } \\
\text { sistem produksi } \\
\text { kerajinan dengan } \\
\text { inspirasi budaya } \\
\text { lokal non benda dan } \\
\text { material daerah } \\
\text { sekitar berdasarkan } \\
\text { daya dukung } \\
\text { yang dimiliki oleh } \\
\text { daerah setempat. } \\
\end{array}$ & $\begin{array}{l}4.3 \text { memproduksi } \\
\text { kerajinan dengan } \\
\text { inspirasi budaya lokal } \\
\text { non benda } \\
\text { dan material dari } \\
\text { daerah sekitar } \\
\text { berdasarkan daya } \\
\text { dukung yang } \\
\text { dimiliki oleh daerah } \\
\text { setempat }\end{array}$ \\
\hline
\end{tabular}

Langkah kedua, guru mata pelajaran menentukan tema yang terinspirasi dari budaya lokal atau keunggulan daerah Sragen. Guru membentuk kelompok wirausahan dan membimbing siswa mulai dari penelitian sederhana untuk mengidentifikasi peluang pasar, menemukan solusi/ide/gagasan, menciptakan produk baik berwujud maupun ide/gagasan, memproduksi produk, memasarkan produk baik offline maupun secara online, dan menyusun laporan. Konsep ekonomi digunakan siswa dalam melakukan penelitian sederhana untuk mengidentifikasi peluang pasar. Dalam menemukan solusi/ide/gagasan serta mewujudkannya menggunakan konsep dasar ekonomi dan prakarya dan kewirausahaan. Konsep dasar mata pelajaran PPKn dan Bahasa Indonesia digunakan siswa untuk menyusun laporan kegiatan.

\section{Proyek Kewirausahaan melalui kegiatan ekstrakurikuler}

Kegiatan ekstrakurikuler merupakan kegiatan pembelajaran di luar jam pelajaran terstruktur. Kegiatan ekstrakurikuler mempunyai tujuan utama untuk membantu tercapainya tujuan utama pembelajaran dalam meningkatkan kecakapan siswa dalam ranah kognitif, afektif, dan psikomotor (Jasman Jalil, 2018). Pendidikan kewirausahaan di sekolah dapat diintegrasikan melalui kegiatan ekstrakurikuler untuk memberikan manfaat praktis bagi siswa. Keterlibatan semua peserta didik disetiap kegiatan ekstrakurikuler wirausaha dikatakan sangat baik, karena dapat membuat peserta didik mampu untuk menanamkan tanggung jawab secara mandiri terhadap kegiatan wirausaha, meskipun dalam prakteknya dilakukan melalui kerjasama dengan semua anggota (Su'adiyah et al., 2020). Kegiatan ekstrakurikuler membantu pengembangan siswa yang disesuaikan dengan kebutuhan, potensi, bakat, dan minat siswa yang dibimbing oleh pendidik atau tenaga kependidikan yang ditunjuk oleh sekolah. Contoh kegiatan ekstrakurikuler yang terkait dengan pendidikan kewirausahaan di sekolah misalnya Club Wirausaha, Club Star-up, Kelompok Wirausaha Muda dan lainnya.

Pembelajaran kewirausahaan dapat dilaksanakan melalui kegiatan ekstrakurikuler yang pelaksanaaannya di luar jam pelajaran. Kegiatan ekstrakurikuler kewirausahaan ditujukan untuk menumbuhkan nilai-nilai kewirausahaan dan melatihkan bagaimana menjadi kreatif dan inovatif dengan menciptakan sesuatu yang baru atau membuat sesuatu yang berbeda dengan yang sudah ada sebelumnya. Pelaksanaan kegiatan ekstrakurikuler kewirausahaan meliputi: pemilihan ide, proses produksi, pemasaran produk, pembuatan proposal, dan pelatihan public speaking (Su'adiyah et al., 2020)

Kegiatan kewirausahaan melalui ekstrakurikuler menjadi salah satu pilihan untuk memperdalam pengetahuan, keterampilan dan nilai-nilai wirausahan bagi siswa yang mempunyai minat tinggi untuk menjadi wirausaha. Bentuk kegiatan ekstrakurikuler tidak jauh berbeda dengan tahapan pembelajaran proyek. Siswa diberi kebebasan menentukan jenis kreativitas berdasarkan minatnya. Siswa yang memiliki minat sama atau bidang yang sama dapat bekerjasama membentuk kelompok usaha siswa. Sekolah perlu memfasilitasi ketersediaan sarana prasarana, pembimbing, pengelolaan ektrakurikuler termasuk kegiatan Entrepreneur Award, Market Day, Pekan Kewirausahaan, atau aktivitas lain sebagai wadah siswa memperkenalkan hasil karya mereka sekaligus 
sebagai motivasi bagi siswa yang lain. Sekolah dapat bekerjasama dengan komunitas atau dunia usaha dunia industri untuk mengembangkan kegiatan ekstrakurikuler tersebut bahkan dapat memfasilitasi terciptanya usaha kecil mikro menengah yang baru. Kegiatan ektrakurikuler kewirausahaan dapat dikembangkan pula menjadi pusat keunggulan sekolah berbasis kewirausahaan, baik sebagai sumber belajar siswa maupun sebagai unit produksi.

\section{SIMPULAN}

Siswa SMA di Sragen yang memiliki cita-cita menjadi wirausaha masih sedikit, yaitu $16 \%$ dari 1.347 responden Minat wirausaha menjadi faktor penting untuk menumbuhkan perilaku wirausaha. Salah satu upaya menumbuhkan minat wirausaha siswa adalah dengan memberikan pengetahuan. Pengetahuan kewirausahaan siswa SMA diperoleh melalui pembelajaran kewirausahaan. Pembelajaran kewirausahaan selama pandemi lebih memfokuskan pada transfe pengetahuan tentang teori-teori kewirausahaan seperti yang menjadi tuntutan dalam kurikulum mata pelajaran prakarya dan kewirausahaan. Sebagian besar siswa menghendaki pembelajaran kewirausahaan tidak hanya sebatas teori tetapi berbasis praktik.

Pembelajaran kewirausahaan yang dapat menubuhkan minat adalah pembelajaran yang bersifat simulasi dengan berbagai model pembelajaran yang mengarah pada keterampilan berpikir dan kreativitas. Upaya meningkatkan kualitas pembelajaran kewirausahaan di sekolah dapat dilakukan melalui kegiatan intrakurikuler, kokurikuler, dan ekstrakurikuler. Pendekatan yang dipilih guru seharusnya merangsang siswa untuk berpikir kreatif. Pembelajaran dapat dilakukan dengan menerapkan pembelajaran proyekdengan memanfaatkan dan mengembangkan potensi lokal yang ada di daerahnya. Pembelajaran lain yang dapat diterapkan adalam model design thinking yang menyajikan pendekatan solusi untuk memecahkan masalah. Pembelajaran dimulai dengan mengidentifikasi keinginan atau selera konsumen, merumuskan masalah dan solusi pemecahan masalah, proses pengumpulan ide melalui curah pendapat, membuat purwarupa dan mengujinya untuk dasar perbaikan purwarupa.

Kewirausahaan selain diajarkan melalui mata pelajaran wajib, dapat juga dilakukan melalui proyek kokurikuler. Proyek kewirausahaan dilakukan dengan mengkolaborasikan kompetensi dasar atau capaian pembelajaran dari berbagai mata pelajaran. Dengan adanya kolaborasi antar mata pelajaran, siswa dapat mempelajari dan memperdalam kompetensi dari berbagai sudut pandang. Bentuk proyek kokurikuler dapat melatihkan siswa bagaimana bekerjasama, menghargai pendapat teman, menemukan ide-ide kreatif untuk memecahkan masalah, memanfaatkan teknologi untuk menunjang proyek mereka.

Kewirausahaan di sekolah dapat juga dikembangkan melalui kegiatan ekstrakurikuler yang disesuaikan dengan kebutuhan, potensi, bakat, dan minat siswa yang dibimbing oleh pendidik atau tenaga kependidikan yang ditunjuk oleh sekolah. Pelaksanaannya diluar jam pelajaran, yang sifatnya tidak wajib bagi siswa. Dalam mengembangkan kegiatan ekstrakurikuler kewirausahaan, siswa didampingi oleh pelatih atau pembina yang dapat berasal dari guru maupun tenaga kependidikan bahkan dapat pula pendamping dari dunia usaha dunia industri. Kegiatankegiatan untuk memamerkan produk hasil karya siswa dijadwalkan secara berkala.

\section{DAFTAR PUSTAKA}

Badan Pusat Statistik. (2019). Statistik Mobilitas Penduduk dan Tenaga Kerja 2019.

https://bps.go.id/indikator/indikator/view/0000/publ ication/4e56f5c350dda045f875f66c/pub_02

Bender, W. N. (2012). Project-Based Learning: Differentiating Instruction for the 21st Century. In CORWIN a Sage Company (Vol. 92, Issue 5). Corwin.

http://proxy.libraries.smu.edu/login?url=http://searc h.ebscohost.com/login.aspx ?direct=true $\& \mathrm{db}=$ eue $\&$ $\mathrm{AN}=87934923 \&$ site $=$ ehost-live $\&$ scope $=$ site

Blazely, L. (1997). Science Study. The Grand Japan Foundation.

Bliemel, M. J. (2013). Getting Entrepreneurship Education Out of the Classroom and into Students' Heads. Entrepreneurship Research Journal, 4(2), 237-260. https://doi.org/10.1515/erj-2013-0053

Brolin, D. (1989). Life Centered Career Education: A. Competency, Based Approach Reston VA. The Council for Exeptional University.

Doppelt, Y. (2003). Implementing and Assessment of PBL in a Flexible Environment. International Journal Of Technology and Design Education, 13(3), 255-272.

https://link.springer.com/article/10.1023/A:102612 5427344\%5Cnhttp://cedu521-k-

f07.pbworks.com/f/Implementation+and+Assessme nt+of+Project-

Based+Learning+in+a+Flexible+Environment.pdf

Jasman Jalil. (2018). Pendidikan Karakter Implementasi oleh Guru dan Sumber daya Pendidikan. In $C V$ Jejak (Issue CV Jejak). CV. Jejak.

Kasmir. (2006). Kewirausahaan. PT Raja Grafindo Persada.

Kemendikbud. (2019). Pedoman Program Kewirausahaan SMA. 57. 
Matlay, H., \& Carey, C. (2007). Entrepreneurship education in the UK: A longitudinal perspective. Journal of Small Business and Enterprise Development, 14(2), 252-263. https://doi.org/10.1108/14626000710746682

McClure, K. R. (2015). Exploring Curricular Transformation to Promote Innovation and Entrepreneurship: An Institutional Case Study. Innovative Higher Education, 40(5), 429-442. https://doi.org/10.1007/s10755-015-9325-8

Mcstay, D. (2008). An investigation of undergraduate student self-employment intention and the impact of entrepreneurship education and previous entrepreneurial experience Presented By. Behaviour.

Mulyani, E. (2014). Developing an Enterpreneurship Education Project-Based. Cakrawala Pendidikan, XXXIII/no., 50-61.

Munawar, A., \& Suryana. (2020). the Influence of Entrepreneurial Learning and the Motivation To the Entrepreneurial Interest of Students. Jurnal Masyarakat Mandiri, 4(3), 424-435.

Mustakim, M. (2020). Efektivitas Pembelajaran Daring Menggunakan Media Online Selama Pandemi Covid-19 Pada Mata Pelajaran Matematika. Al Asma : Journal of Islamic Education, 2(1), 1. https://doi.org/10.24252/asma.v2i1.13646

Nguyen, T. (2015). The Effectiveness of Online Learning: Beyond No Significant Difference and Future Horizons. MERLOT Journal of Online Learning and Teaching, 11(2), 309-319.

Noviani, L., Sabandi, M., Maret, U. S., \& Maret, U. S. (2020). PEMBELAJARAN EKONOMI BERBASIS LIFE SKILLS SEBAGAI SOLUSI PADA SITUASI PANDEMI COVID-19. 99-105.

PH, S. (2002). Pendidikan Kecakapan Hidup: Konsep Dasar. Jurnal Pendidikan Dan Kebudayaan. Balitbang Diknas., 8(037), 541-561.

Philip, U. I., Badiya, M., Ahmadu, H., \& Kabiru, Y. (2016). Perceptions of entrepreneurship education by engineering students of Modibbo Adama University of Technology, Yola, Nigeria. African Journal of Business Management, 10(14), 352-360. https://doi.org/10.5897/ajbm2016.8049

Purusottama, A., \& Akbar, T. F. (2019). An Entrepreneurship Education Model for Promoting Students' Entrepreneurial Intentions: The Case of Indonesian Higher Education. Indonesian Journal of Business and Entrepreneurship, 5(2), 138-147. https://doi.org/10.17358/ijbe.5.2.138

Purwana, D. \& Wibowo, A. (2017). Pendidikan kewirausahaan di perguruan tinggi: Strategi, sukses membangun karakter dan kelola usaha.
Pustaka Pelajar.

Raharjo, N. E. (2016). Model Pendidikan Karakter Kewirausahaan Melalui Unit Produksi Dan Jasa Di Smkn 2 Pengasih. Jurnal Pendidikan Teknologi Dan Kejuruan, 13(1), 98-110. https://doi.org/10.23887/jptk.v13i1.6850

Sragen, B. K. (2020). Statistik Daerah Kabupaten Sragen. sragenkab.bps.go.id

Su'adiyah, R. L. Q., Wahid, A., \& Fahrurrozi, F. (2020). Manajemen Kurikulum Ekstrakurikuler Kewirausahaan dalam Membentuk Jiwa Entrepreneur Peserta Didik di SMA Mazra'atul Ulum Paciran Lamongan. Jawda: Journal of Islamic Education Management, 1(1), 1. https://doi.org/10.21580/jawda.v1i1.2020.6672

Tanjaya, C., \& Radianto, W. E. (2020). Entrepreneurial Knowledge, Entrepreneurial Intention, Dan Entrepreneurial Orientation Pada Pendidikan Ilmu Akuntansi. Media Akuntansi Dan Perpajakan Indonesia, 1(2), 135-152. https://doi.org/10.37715/mapi.v1i2.1406

Widiarto, Chr. Argo, Wiwik Kusdaryani, A. S. (2015). Pembelajaran berbasis proyek pada mata kuliah psikologi kewirausahaan dalam meningkatkan sikap. Media Penelitian Pendidikan: Jurnal Penelitian Dalam Bidang Pendidikan Dan Pengajaran, 8(2).

Wikanta, W., \& Gayatri, Y. (2017). Pembelajaran Berbasis Proyek Dalam Menanamkan Karakter Kewirausahaan, Keterampilan Proses Sains, Dan Keterampilan Berpikir Tingkat Tinggi Mahasiswa. Jurnal Ilmu Pendidikan, 23(2), 171-175. 